\title{
Modelling effect of temperature and irradiance changes of Assa, Morocco on photovoltaic modules' performance
}

\author{
Siham Chakiri ${ }^{*}$, My Tahar Lamchich ${ }^{1}$ \\ ${ }^{1}$ Intelligent Energy Management and Information Systems Laboratory, Cadi Ayyad University-FSTG, 2390, Marrakesh, Morocco
}

\begin{abstract}
A mathematical representation of a photovoltaic (PV) solar cell and module performances is demonstrated in this paper. One diode based on the Shockley diode equation model is adopted for simulation and extract the performance indications. The simulated solar module is a particular $235 \mathrm{~W}$ solar module operating in an existing $806.52 \mathrm{kWp}$ grid connected photovoltaic power plant located at Assa, southern Morocco. The model demonstrates power-voltage (P-V) and current-voltage (I-V) characteristic curves with weather conditions changes. These external conditions include temperature and solar irradiance level (represented by sun unit $1 \mathrm{sun}=1000 \mathrm{w} / \mathrm{m}^{2}$ ) which greatly affect the performance of the PV system. This paper also presents PV simulation with a maximum power point tracking (MPPT) converter and the general model was implemented in Matlab/Simulink software and used as an example verifying the performance of the tested module under Assa city weather variable.
\end{abstract}

\section{Introduction}

The environmental pollution problems based on classic energy forms cause the planet to be hostile due to the climate changes and other geo and hydro contaminations. In today's world, there is a need to focus on renewable energy sources to decrease the dependence on fossil fuels resources, and reduce the emission of greenhouse gases. Also deregulation of the electric utility industry is providing an opportunity for higher penetration and use of this resources. Most renewable energy sources start either directly or indirectly from the sun, solar energy is expected to play a very significant role in the future especially in developing countries.

With a high radiation level with an average value of about $5 \mathrm{KWh} / \mathrm{m}^{2} /$ day and illumination hours of more than 3000 hours/year, Morocco has opted for a national energy strategy aiming to increase the contribution of renewable energies up to $52 \%$ by 2030 to satisfy the country 'ever increasing energy demand [1]. Photovoltaic is one of the most used technologies to convert solar energy into electricity. Solar cell is a p-n junction fabricated in a thin wafer or layer of semiconductor (usually silicon). In the dark the I-V output of a solar cell has an exponential characteristic similar to that of a diode, when exposed to light, photons with energy greater than the bandgap energy of the semiconductor are absorbed and create an electron-hole pair. These carriers are swept apart under the influence of the internal electric fields of the $p-n$ junction and thus creating a photo generated current proportional to the incident radiation. The amount of power delivered by a photovoltaic cell is usually limited to a few watts, about 1 or $2 \mathrm{~W}$ of power approximately depends of the type of material used and the limited surface area. To increase the power output to hundreds of watts, the photovoltaic cells can be grouped together to form higher power modules. Likewise, depending on the capacity of the power plant or the electricity production, groups of modules can be connected together ((in series, parallel or both) to form an array with a power range of kilowatts to megawatts. The output current, voltage and power of the PV panel can be fluctuating depending on the weather conditions. Efficient simulations of a system including PV panel are required and power converters with MPPT control to provide a reliable useful energy becomes indispensable. In practical use there are various MPPT techniques; perturbation and observation (P\&O) [8], incremental conductance [9], Hill climbing, fractional short circuit current and voltage and Neural Networks methods are popular used in the MPPT controllers due to their easy implementation, simplicity and fast response [10].

This paper refers to a detailed simulation model for PV module based on the Shockley's diode equation to evaluate the performance represented by $\mathrm{P}-\mathrm{V}$ and I-V characteristic curves of a $235 \mathrm{~W}$ power PV module with ASSA radiation and temperature degree conditions. The PV generator is then interfaced with a MPPT boost converter to evaluate the behaviour of all the system.

\footnotetext{
*Corresponding author: siham.chakiri@gmail.com
} 


\section{Photovoltaic (PV) system modelling}

\subsection{Photovoltaic solar cell modelling}

In order to study the behavior of solar cells, different models have been developed. To reduce the number of equations to be solved and simplify the equivalent circuit and due to its simple programming using the Matlab software package, the simple diode solar cell model as shown in Figure 1 is adopted [2, 3]. In the absence of solar radiation, the solar cell's behavior is a diode and can be represented by the Shockley equation given as (1):

$$
I_{d}=I_{s}\left(e^{\left(\frac{V_{P V}}{V_{T}}\right)}-1\right)
$$

The thermal voltage is given by equation (2):

$$
V_{T}=\frac{K x A x T_{c k}}{q}
$$

When the PV cell is ideal it is sufficient to be modelled with a parallel source current with a diode. The current source represents the intensity of solar radiation and the diode represents the behavior of $p-n$ junction. The basic equation in semiconductor theory that mathematically describes the I-V characteristic of the ideal PV cell is (3):

$$
I_{P V}=I_{P H}-I_{d}=I_{P H}-I_{S}\left(e^{\left(\frac{V_{P V}}{V_{T}}\right)}-1\right)
$$

A serie $\left(R_{s}\right)$ and parallel $\left(R_{p}\right)$ resistances are inserted in the ideal model of solar cell.

$R_{S}$ Reflects to the losses caused by the resistance of the material and connections while $R_{p}$ introduces the effect of leakage current [4]. Generally, the series resistance $R_{s}$ value is very small, whereas $R_{p}$ has a very high value and it can be ignored. The output relation of the current becomes (4):

$$
I_{P V}=I_{P H}-I_{S}\left(e^{\left(\frac{V_{P V}+R_{S} x I_{P V}}{V_{T}}\right)}-1\right)-\frac{V_{P V}+R_{S} x I_{P V}}{R_{p}}
$$

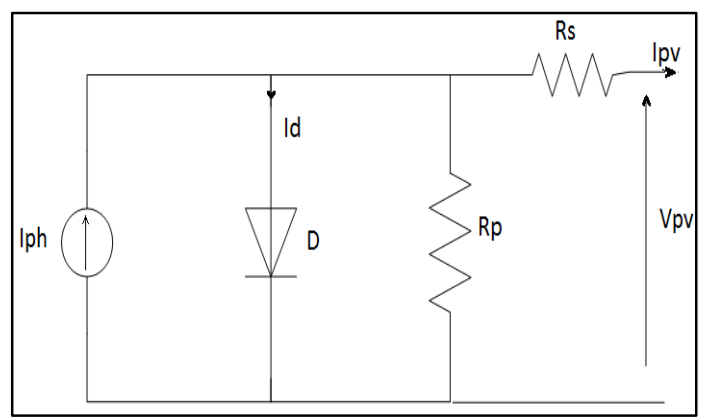

Fig. 1. Circuit diagram of one diode PV model.

\subsection{Photovoltaic module modelling}

A PV module is made by connecting $\mathrm{N}$ cells in series and parallel. The connection of cells in series increases the voltage while connecting them in parallel increases the output current. A panel with the cells connected in series can be described by Equation (4) by adding the number of cells $\mathrm{N}$ to the relation (2) of $V_{T}$ as follows (5):

$$
V_{T}=\frac{N x K x A x T_{c k}}{q}
$$

\subsection{Photovoltaic array modelling}

The PV array is a serial/parallel association of Ns/Np elementary modules to increase voltage or overall current, if all the cells are identical and operate under the same conditions the electrical model of the PV array based on the single diode model is given by the following equation (6):

$$
\begin{aligned}
I_{P V}= & N_{p} x I_{P H}-N_{p} x I_{S}\left(e^{\frac{1}{V_{T}}\left(\frac{V_{P V}}{N_{S}}+\frac{R_{S} x I_{P V}}{N_{p}}\right)}-1\right) \\
& -\frac{N_{P}}{R_{S}}\left(\frac{V_{P V}}{N_{S}}+\frac{R_{S} x I_{P V}}{R_{p}}\right)
\end{aligned}
$$

The different parameters of the math modelling equations above are determined by the expressions below:

$$
\begin{gathered}
I_{P H}=\left(\frac{G}{G_{n}}\right) I_{s c(T 1)}+K_{i}\left(T-T_{1}\right) \\
K_{i}=\frac{I_{S c(T 2)}-I_{s c(T 1)}}{T_{2}-T_{1}} \\
I_{S}=I_{0(T 1)} x\left(\frac{T}{T_{1}}\right)^{3 / n} e^{\frac{-q V g}{A k}\left(\frac{1}{T}-\frac{1}{T_{1}}\right)} \\
I_{0(T 1)}=\frac{I_{S c(T 1)}}{\left(e^{\left(\frac{q V_{o c(T 1)}}{A k T 1}\right)}-1\right)} \\
R_{S}=-\frac{d V}{d I_{V o c}}-\frac{1}{X_{V}} \\
X_{V}=I_{0(T 1)} \frac{q}{A k T_{1}} e^{\left(\left(\frac{q V_{o c(T 1)}}{A k T_{1}}\right)\right)}-\frac{1}{X_{V}}
\end{gathered}
$$

\section{PV system modelling with a DC-DC Boost converter}

\subsection{Modelling of PV system}

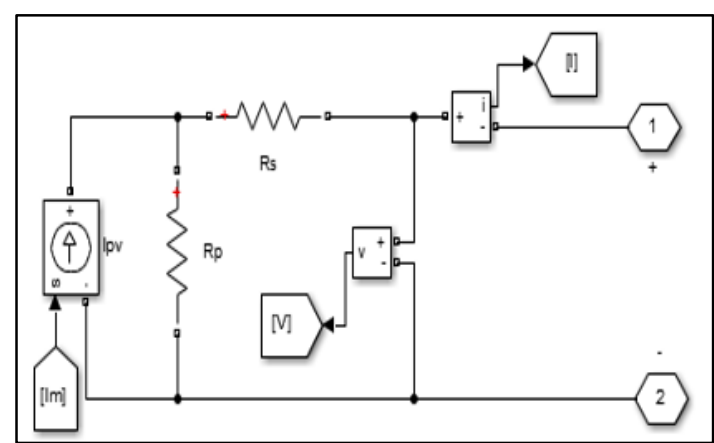

Fig. 2. Simulink model of the PV module based one diode model.

The model of the PV module has been designed in Matlab/Simulink based on the mathematical equations as shown in Figure 2.

\subsection{DC-DC Boost converter modelling}

The boost converter consists of a DC input voltage source $V_{i n}$, an inductor $\mathrm{L}$, a switch $\mathrm{S}$, a diode, and two capacitors $C_{i n}$ and $C_{\text {out }}$. It is used as an interface to convert a low input voltage into a high output voltage, 
in PV systems it is also used to track Maximum Power Point (MPP) in the P-V curves of the PV modules regardless of the temperature and irradiance differences.

Figure 3 shows the electrical diagram of the boost converter in Matlab Simulink. The relationship between the input voltage $V_{\text {in }}$ and the output voltage $V_{\text {out }}$ of the converter is given by equation (13).

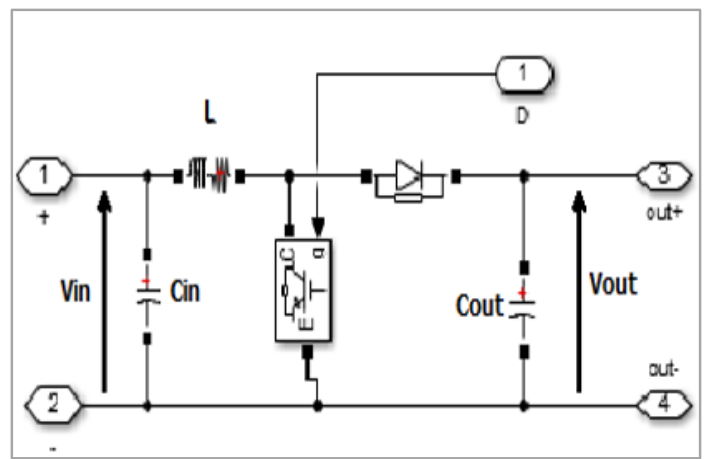

Fig. 3. Boost converter in Matlab Simulink.

$$
V_{\text {out }}=\frac{V_{\text {in }}}{1-D} \quad \text { And } \quad I_{0}=I(1-D)
$$

where $V_{i n}=V_{P V}$ and $I=I_{P V}$. The expressions for capacitance and inductance are given by equations (14) and (15), respectively.

$$
\begin{aligned}
& C=\frac{D * V_{0}}{f_{S} * R * \Delta V} \\
& L=\frac{D * V}{f_{S} * \Delta I}
\end{aligned}
$$

$\mathrm{D}$ is the duty cycle, fs is the frequency of the transistor, $\Delta \mathrm{V}$ is the tolerable voltage limit, $\Delta \mathrm{I}$ is the tolerable current limit and $\mathrm{R}$ is the load resistance. The duty cycle is the output of the MPPT control system and it is compared with a repeating sequence to produce a PWM signal. By modifying the converter duty cycle, the source impedance can be matched to the load impedance to maximize power output.

Each time the output power of the boost converter is compared to the previous power of the module and the converter duty cycle is adjusted accordingly to follow the point of maximum power. The Perturb and Observe (P\&O) MPPT algorithm is used because it has a very fast response with the best result as it quickly reaches the steady state operation stage. The P\&O method is implemented in Figure 4.

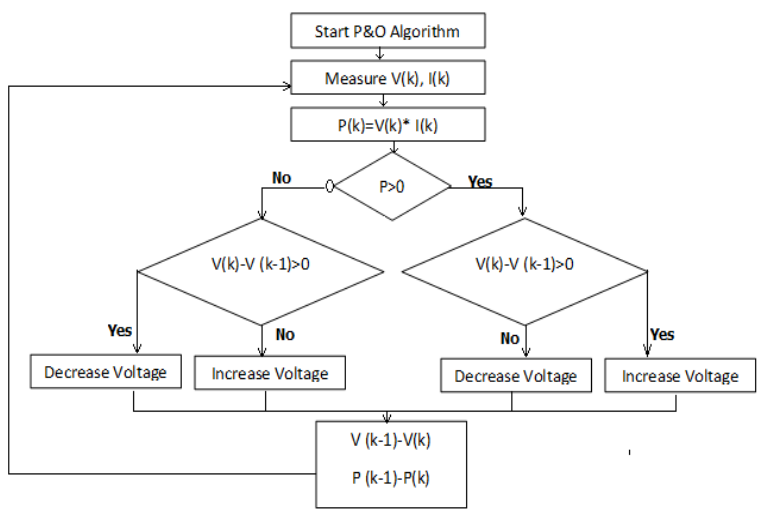

Fig. 4. Flowchart for the Perturb and Observe MPPT method.

\section{Simulation result}

The resolution of the current solar module equation is a non-linear problem that can be solved using numerical methods.

Table 1. Specifications of NU-25E1H PV module.

\begin{tabular}{|l|c|c|}
\hline \multicolumn{1}{|c|}{ Parameter } & Variable & Value \\
\hline Maximum power & $\mathrm{Pm}$ & $235 \mathrm{~W}$ \\
\hline Voltage at MPP & $\mathrm{Vm}$ & $30.3 \mathrm{~V}$ \\
\hline Current at MPP & $\mathrm{Im}$ & $7.76 \mathrm{~A}$ \\
\hline Short circuit current & $\mathrm{Isc}$ & $8.49 \mathrm{~A}$ \\
\hline Open circuit voltage & $\mathrm{Vco}$ & $37.9 \mathrm{~V}$ \\
\hline $\begin{array}{l}\text { Temperature coefficient } \\
\text { of open circuit voltage }\end{array}$ & $\boldsymbol{\beta}$ & $-130 \mathrm{mV} /{ }^{\circ} \mathrm{C}$ \\
\hline $\begin{array}{l}\text { Temperature coefficient } \\
\text { of short circuit current }\end{array}$ & $\mathrm{A}$ & $+0.053 \% /{ }^{\circ} \mathrm{C}$ \\
\hline $\begin{array}{l}\text { Temperature coefficient } \\
\text { of power }\end{array}$ & & $-0.485 \% /{ }^{\circ} \mathrm{C}$ \\
\hline $\begin{array}{l}\text { Number of cells in a PV } \\
\text { module }\end{array}$ & \multicolumn{2}{|l}{60} \\
\hline
\end{tabular}

The literature indicates the fast convergence of the Newton Raphson iterative method [5, 6], this technique has been exploited in this work for every voltage to find $\mathrm{I}-\mathrm{V}$ and then P-V curves of solar module under the effect of temperature and irradiation of Assa province. The idea is to represent $(\mathrm{I}-\mathrm{V})$ characteristic of a solar module as a function of temperature, voltage and irradiation $\mathrm{Ia}=\mathrm{f}(\mathrm{Va}, \mathrm{G}, \mathrm{T})$, where $\mathrm{Va}, \mathrm{Ia}, \mathrm{G}$, and $\mathrm{T}$ are the terminal operation voltage, the terminal operation current of the solar module, the irradiation level and the temperature, respectively. Then, the solar module output power $\mathrm{P}$ can be calculated as: $\mathrm{P}=\mathrm{Va}$ * Ia $=\mathrm{f}(\mathrm{Va}, \mathrm{G}, \mathrm{T}) * \mathrm{Va}$. This can be written by equation (16):

$$
I_{a}=I_{a}-\frac{\left(I_{P H}-I_{a}-I_{S}\left(e^{\left(\frac{V_{o c}+R_{S} x I_{a}}{V_{T}}\right)}-1\right)\right)}{-1-\left(I_{S}\left(e^{\left(\frac{V_{C}+R_{S} x I_{a}}{V_{T}}\right)}-1\right)\left(\frac{R_{S}}{V_{T}}\right)\right)}
$$

The Newton-Raphson algorithm can be implemented easily in a program. A Matlab ${ }^{\mathrm{TM}}$ script divided in four parts is implemented:

1). Definition of constants (k: Boltzmann's constant, q: electron charge, G: irradiation, A: diode ideality quality factor, etc.).

2). Definition of variables.

3). Calculation of $I_{P H}, I_{S}$ and $R_{S}$ (Equations $7-12$ are used).

4). Calculation of Ipv.

The algorithm is descripted as:

$\%$ Module NU-235E1H I-V and P-V characteristics

$\mathrm{G}=$ Suns; $\%\left(1\right.$ Sun $\left.=1000 \mathrm{~W} / \mathrm{m}^{\wedge} 2\right)$

$\mathrm{T}=$ Temperature

$\mathrm{k}=1.38 \mathrm{e}-23 ; \mathrm{q}=1.60 \mathrm{e}-19 ; \mathrm{A}=1.2 ; \mathrm{Vg}=1.12 ; \mathrm{N}=60$;

$\mathrm{T} 1=273+25$;

Voc_T1 $=37.0 / \mathrm{N}$;

Isc_T $1=8.60$;

$\mathrm{T} 2=273+75$

Tark $=273+\mathrm{T}$;

Iph_T1 $=$ Isc_T $1 *$ Suns; $\%$ 
$\mathrm{Ki}=($ Isc_T2 - Isc_T1 $) /(\mathrm{T} 2-\mathrm{T} 1) ; \%$ Equation $(8)$

$\mathrm{Iph}=\mathrm{Iph} \_\mathrm{T} 1+\mathrm{Ki}^{*}(\mathrm{TarK}-\mathrm{T} 1) ; \%$ Equation (7)

$\mathrm{Vt} \_\mathrm{Ta}=\mathrm{A} * \mathrm{k} *$ Tark $/ \mathrm{q}$;

I0_T1=Isc_T1/ (exp (q*Voc_T1/ (A*k*T1))-1);

$\%$ Equation (10)

$\mathrm{b}=\mathrm{Vg} * \mathrm{q} /(\mathrm{A} * \mathrm{k})$

Is= I0_T1*(TarK/T1).^ (3/n).*exp (-b.*((1. /TarK)-

$(1 / \mathrm{T} 1))) ; \%$ Equation (9)

$\mathrm{Xv}=\mathrm{I} 0 \_\mathrm{T} 1 * \mathrm{q} /(\mathrm{n} * \mathrm{k} * \mathrm{~T} 1) * \exp \left(\mathrm{q} * \mathrm{Voc} \_\mathrm{T} 1 /(\mathrm{n} * \mathrm{k} * \mathrm{~T} 1)\right)$;

$\%$ Equation (12)

dVdI_Voc $=-1.15 / \mathrm{N} / 2$;

$\mathrm{Rs}=-\mathrm{dVdI}$ Voc $-1 / \mathrm{Xv}$; \% Equation (11)

$\mathrm{VC}=\mathrm{Va} / \mathrm{N}$

$\mathrm{Ia}=\operatorname{zeros}(\operatorname{size}(\mathrm{Vc}))$;

$\%$ Newton Raphson method

for $\mathrm{j}=1: 100$;

$\mathrm{Ia}=\mathrm{Ia}-\left(\mathrm{Iph}-\mathrm{Ia}-\mathrm{Is} . *\left(\exp \left((\mathrm{Vc}+\mathrm{Ia} . * \mathrm{Rs}) . / \mathrm{Vt} \_\mathrm{Ta}\right)-1\right)\right) . /(-$ 1 - (Is.*( $\left.\left.\left.\exp \left((\mathrm{Vc}+\mathrm{Ia} . * \mathrm{Rs}) . / \mathrm{Vt} \_\mathrm{Ta}\right)-1\right)\right) . * \mathrm{Rs} . / \mathrm{Vt} \_\mathrm{Ta}\right)$;

end

$\mathrm{Ipv}=\mathrm{Ia}$;

$\mathrm{Ppv}=\mathrm{Va} * \mathrm{Ia}$;

plot (Va,Ipv);

plot (Va,Ppv);

A NU-235E1H module has been tested under the conditions such as changes of radiation and temperature in the ASSA as previously mentioned. The key specifications of the module are shown in Table 1. The measured solar radiation and ambient temperature of the PV plant located at ASSA for one operating day presented in Figure 5 are used as input data. Irradiance $(\mathrm{G})$ is the average instantaneous value over a defined period of time [7], it is a quantity of energy that has applied energy to a given area (watts per square meter $\left.\left(\mathrm{W} / \mathrm{m}^{2}\right)\right)$. Irradiance is usually specified by hour, day or even month. A Pyranometer is used to measure the solar radiation for each 1 minute.

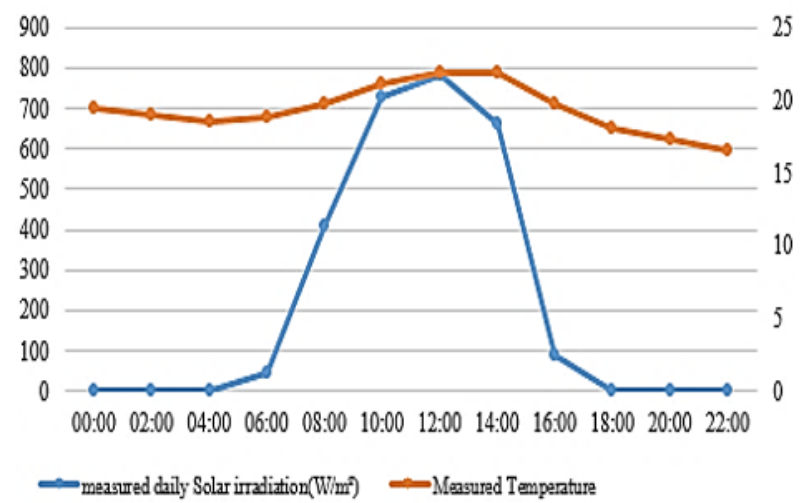

Fig. 5. One-day measured solar irradiation and temperature in ASSA.

The averaged value of the monitored irradiation data are $10.67 \mathrm{w} / \mathrm{m}^{2}$ during the peak period ( $17 \mathrm{~h}$ to $22 \mathrm{~h}$ ), 0.35 $\mathrm{w} / \mathrm{m}^{2}$ during the off-peak period $(22 \mathrm{~h}$ to $07 \mathrm{~h} 00)$ and $538.29 \mathrm{w} / \mathrm{m}^{2}$ during the full period $(07 \mathrm{~h}$ to $17 \mathrm{~h})$ varying from $29.6 \mathrm{w} / \mathrm{m}^{2}$ to $1230 \mathrm{w} / \mathrm{m}^{2}$ as a maximum value. This collected irradiation rang is $\mathrm{G}=$ [from 0.029 to 1.23 ], the values $\left[\begin{array}{llll}0.2 & 0.5 & 1.0 & 1.2\end{array}\right]$ are adopted for the simulation. The average temperature values are $20.83{ }^{\circ} \mathrm{C}$ during the peak period (17h to $22 \mathrm{~h}$ ), $17.75{ }^{\circ} \mathrm{C}$ during the off-peak period (22h to $07 \mathrm{~h} 00)$ and $18.013{ }^{\circ} \mathrm{C}$ during the full period $\left(07 \mathrm{~h}\right.$ to $17 \mathrm{~h}$ ) varying from $18.6^{\circ} \mathrm{C}$ to $22.9^{\circ} \mathrm{C}$.

The P-V and I-V curves are plotted in different colors to differentiate them. Each curve explains the electrical behavior produced by a module under different irradiation and temperature levels.

Figure 6 presents the I-V characteristic of the solar module under variable irradiation values and at constant temperature, it can be seen that the higher the irradiation, the higher the current. It was also noted that the reduction in irradiation will result in a decrease in the output voltage of the panel.

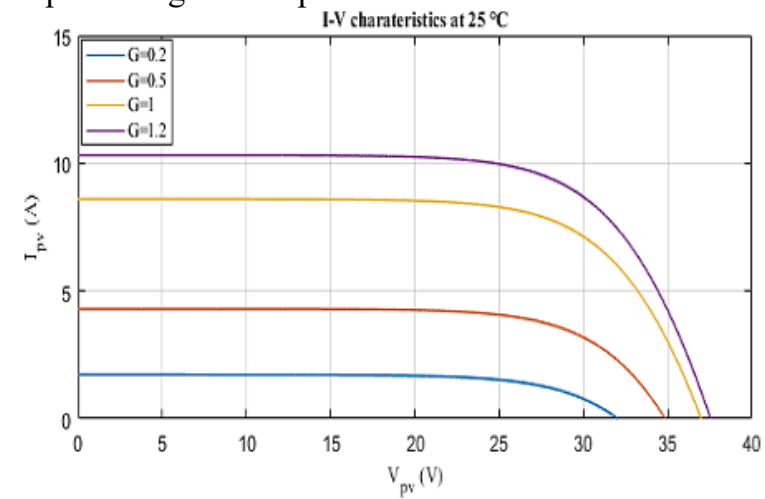

Fig. 6. I-V curves at different values of solar irradiation (NU$235 \mathrm{E} 1 \mathrm{H}, \mathrm{G}=[0.2,0.5,1,1.2]$ sun, $\mathrm{T}=25^{\circ} \mathrm{C}$.

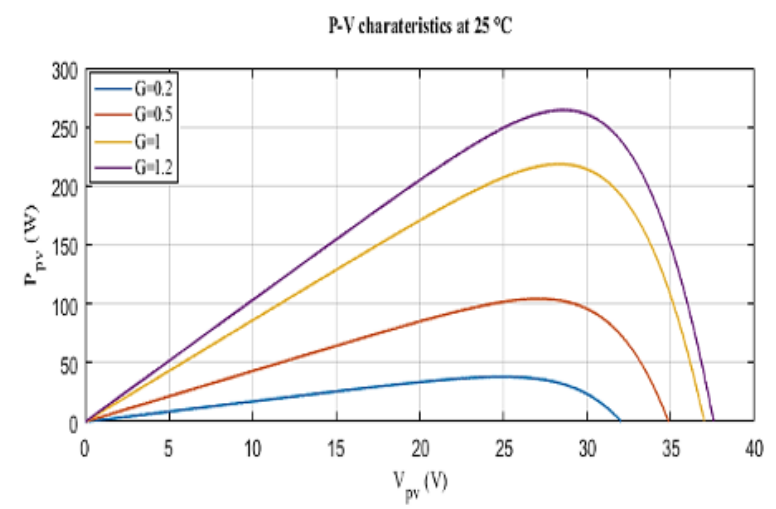

Fig. 7. $\mathrm{P}-\mathrm{V}$ curves at different values of solar irradiation (NU$235 \mathrm{E} 1 \mathrm{H}, \mathrm{G}=[0.2,0.5,1,1.2]$ sun, $\mathrm{T}=25^{\circ} \mathrm{C}$.

Figure 7 shows the effect of different irradiations on the power production of the NU-235E1H solar module at a constant temperature of 25 degree Celsius. The power obtained when $\mathrm{G}=0.2$ is the minimum, while the power obtained at $\mathrm{G}=1.2$ is the maximum. It should be noted that the power value in Table 1 for the NU-235E1H solar module is $235 \mathrm{~W}$, which corresponds to the power value when $\mathrm{G}=1000 \mathrm{~W} / \mathrm{m}^{2}$. With $\mathrm{G}=1$ sun, the open circuit voltage Voc has decreased slightly with increasing cell temperature while the short circuit current Isc has increased, making the cell less efficient. However, when the temperature decreased for the same irradiation, the open circuit voltage increased as shown in Figure 8. Figure 9 shows the effect of cell temperature variation on photovoltaic production for $\mathrm{G}=1$ solar radiation. The maximum power is extracted at $18.9{ }^{\circ} \mathrm{C}$, while the minimum power is extracted at $45^{\circ} \mathrm{C}$. Figure 10 depicts the output power from DC-DC boost converter for a constant value of irradiation $\left(\mathrm{G}=1000 \mathrm{w} / \mathrm{m}^{2}\right)$ (Figure 
10.a) and for irradiation variation shown in Figure 5 shown before (Figure 10.b). The maximum power is 235 Watt which duplicates the maximum power of NU235E1H Solar module in the P-V curve.

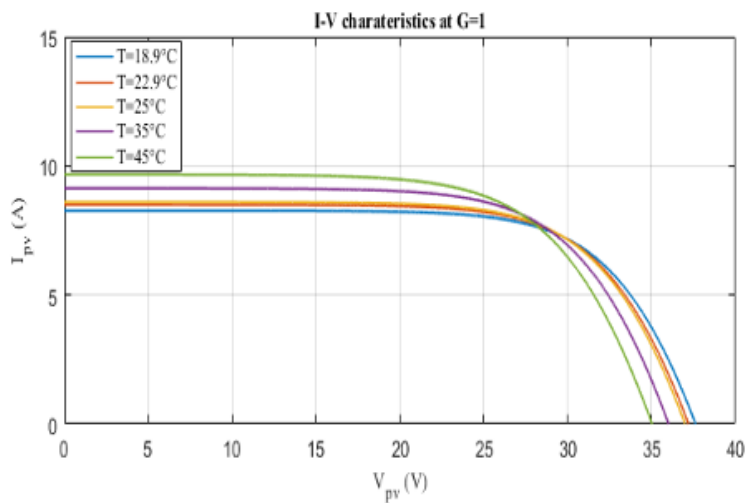

Fig. 8. $I-V$ curves at different values of temperature (NU$235 \mathrm{E} 1 \mathrm{H}, \mathrm{G}=1$ suns, $\mathrm{T}=[18.9,22.9,25,35,45]{ }^{\circ} \mathrm{C}$.

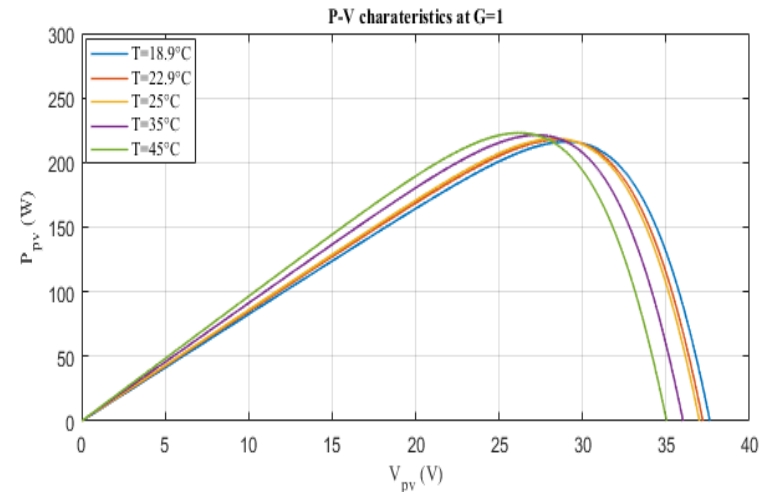

Fig. 9. $\mathrm{P}-\mathrm{V}$ curves at different values of temperature (NU235E $1 \mathrm{H}, \mathrm{G}=1$ suns, $\mathrm{T}=[18.9,22.9,25,35,45]^{\circ} \mathrm{C}$.

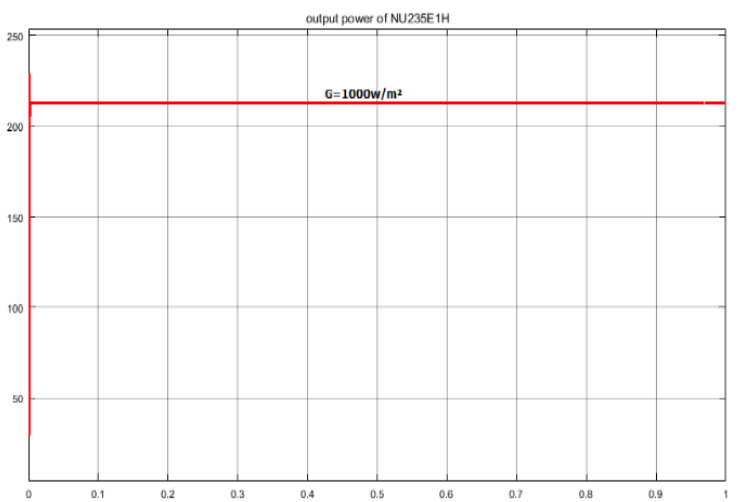

(a)

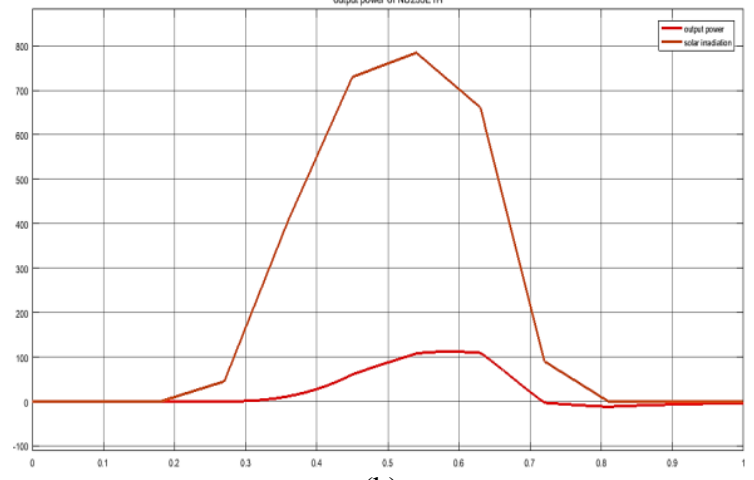

(b)

Fig. 10. Output power of the MPPT Boost converter (a) for $\left(\mathrm{G}=1000 \mathrm{w} / \mathrm{m}^{2}\right)$, (b) for variable irradiations.

\section{Conclusion}

In this paper the one diode equivalent electrical model for a $235 \mathrm{~W}$ PV module using the Shockley diode circuit equations and taking into account the effects of irradiation and temperature in Assa, Morocco is presented by Matlab Simulink. This work is the first step in the development of a general model to simulate the behavior of a grid connected PV system also it can be used as reference to evaluate and compare any other PV modules installed in this area.

\section{References}

1. http://www.abhatoo.net.ma/maalamatextuelle/developpement-economique-etsocial/developpement-economique/energie-etmines/politique-energetique/strategie-energetiquenationale-horizon-2030

2. S. Sholapur, K.R. Mohan, and T.R. Narsimhegowda, IOSR J. Electr. Electron. Eng, 9, 50-56 (2014)

3. S. Umashankar, K.P. Aparna, R. Priya, and S. Suryanarayanan, Int. J. Latest Res. Eng. Technol, 1, 9-16 (2015)

4. C. Carrero, J. Amador, and S. Arnaltes, Renew. Energy, 32, 2579-2589 (2007)

5. A. K. Singhal and R. Narvey, Elixir Int. J, 4, 511$520(2011)$

6. O. Murat, K. Hasan, A. Abdi, and P. Huuml seyin, Int. J. Phys. Sci, 8, 1017-1021 (2013)

7. A. Lavanya, K. Vijaya kumar, and J. D. Navamani, Int. J. Power Electron. Drive Syst, 8, 804-811, (2017)

8. S. Pg, M. E. Control, and N. Maharashtra, 1820 1825 (2017)

9. X. Cai, B. Fu, Y. Huang, X. Xing, L. Yu, and N. Yi, In IASP, IEEE, 1-4 (2011)

10. B. Subudhi and R. Pradhan, Sustain. Energy, IEEE Trans., 4, 89-98 (2013) 